\title{
Allelopathic activity of micropropagated Hyssopus officinalis L., Lamiaceae, water infusions
}

\author{
Asya P. Dragoeva," Zheni D. Nanova, Vanya P. Kalcheva \\ Department of Biology, University of Shumen, Shumen 9712, str. "Universitetska” 115, Bulgaria.
}

\begin{abstract}
RESUMO: "Atividade alelopática de micropropagado Hyssopus officinalis L. infusãos aquosos". Os hábitats naturais de Hyssopus officinalis L. (Lamiaceae) na Bulgária não são suficientes para satisfazer as necessidades desta erva. A micropropagação poderia ser usada para obter plantas com características desejáveis. Hyssopus é uma planta aromática medicinal que não foi estudada muito. Recentemente plantas aromáticas foram investigadas como potentes plantas alelopáticas. A determinação dos modos da ação de aleloquímicos é um dos aspectos desafiantes em estudos alelopáticos. O objetivo deste estudo foi determinar a atividade alelopática de micropropagado Hyssopus officinalis L. infusãos aquosos. Foi avaliada a influência de infusões quentes e frias feito de partes aéreas de hyssopus sob condições de laboratório. Com este propósito nós testou os efeitos de infusões em germinação e alongamento de raiz de Cucumis sativus L. e Triticum aestivum L. Determinamos também o efeito na atividade mitótica usando os Allium cepa L. teste de aberração cromossômica. Os resultados demonstraram a presença de compostos alelopáticos solúveis de água em tecido de hyssopus. As infusões exibiram o efeito depressivo do crescimento que era mais forte na fase inicial de crescimento. Os efeitos inibitivos em germinação e alongamento de raiz foram mais fortes em T. aestivum que em C. sativus. Hyssopus também exerceu efeito genotóxico e mitodepressivo em células de ponta de raiz de Allium cepa.
\end{abstract}

Unitermos: Allium cepa L. teste de aberração cromossômica, germinação, Hyssopus officinalis L., atividade mitótica, elongación de raiz, aleloquímicos solúvel em água.

\begin{abstract}
The natural habitats of Hyssopus officinalis L. (Lamiaceae) in Bulgaria are not sufficient to satisfy the needs of this herb. Micropropagation might be used for obtaining plants with desirable traits. Hyssopus is a medicinal aromatic plant that has not been studied very much. Recently aromatic plants were investigated as potent allelopathic plants. Determining the modes of action of allelochemicals is one of the challenging aspects in allelopathic studies. The objective of this study was to determine the allelopathic activity of micropropagated Hyssopus officinalis L. water infusions. We evaluated the influence of hot and cold infusions made from the aerial parts of hyssopus under laboratory conditions. For this purpose we tested the effects of infusions on germination and root elongation of Cucumis sativus L. and Triticum aestivum L. We determined also the effect on mitotic activity using Allium cepa L. chromosome aberration test. The results demonstrated the presence of water soluble allelopathic compounds in hyssopus tissue. Infusions exhibited growth depressive effect which was stronger at early stage of growth. The inhibitory effects on germination and root elongation were stronger in T. aestivum than in C. sativus. Hyssopus also exerted mitodepressive and genotoxic effect in Allium cepa root tip cells.
\end{abstract}

Keywords: Allium cepa L. chromosome aberration test, germination, Hyssopus officinalis L., mitotic activity, root elongation, water soluble allelochemicals.

\section{INTRODUCTION}

The natural habitats of Hyssopus officinalis L., Lamiaceae, in Bulgaria are not sufficient to satisfy the needs of this herb (Ganchev, 1995). Domesticated cultivation of medicinal plants is clearly a sustainable alternative in order to preserve the wild wealth and increase the farm income of farmers (Basotra et al., 2005). The major problem in the use of phytopharmaceuticals from the Lamiaceae family is the plant-to-plant variability of metabolites due to genetic heterogeneity (Shetty, 2001). Micropropagation procedures are nowadays used for obtaining of valuable individuals starting from a donor plant with high productive capacity (Chun et al., 2005).

Hyssopus is important medicinal aromatic plant that has not been studied very much (Jankovský \& Landa, 2002). Recently, aromatic plants were investigated as potent allelopathic plants. Kazinczi (1999) reported that hyssopus 
was determined as a plant which contained allelochemicals. Several studies have demonstrated the allelopathic activity of essential oils (Dudai et al., 1999; Angelini et al., 2003; Arminante et al., 2006). There are also some data about the presence of water soluble allelopathic substances in aromatic plants (Đikić, 2005; Economou et al., 2007). Allelochemicals may be selective in their action, or plants may be selective in their responses (Einhellig, 1995). So, determining the modes of action of allelochemicals is one of the challenging aspects in allelopathic studies (Chou, 1999).

The objective of this study was to evaluate the allelopathic activity of water infusions made from the aerial parts of micropropagated hyssopus under laboratory conditions using: i. germination and root elongation of Cucumis sativus L. and Triticum aestivum L. and ii. Allium cepa $\mathrm{L}$. chromosome aberration test.

\section{MATERIAL AND METHODS}

\section{Plant material}

In vitro propagation of Hyssopus officinalis L., Lamiaceae, was initiated from stem tips with a length 3-4 cm, taken at the beginning of April (2004) from a plant, grown under controlled conditions (Nanova et al., 2007). Hyssopus plants were grown in the experimental field of the Agricultural Institute-Shumen (latitude $43^{\circ} 18^{\prime}$ $\mathrm{N}$; longitude $27^{\circ} 01^{\prime} \mathrm{E}$, altitude $227 \mathrm{~m}$ ) and collected in the summer of 2006. For allelopathic studies, seeds of C. sativus L. cv. Gergana, T. aestivum L. cv. GTW Milena and A. сера L. cv. Shtuttgarter Riesen were used.

\section{Plant infusions}

We used aerial parts of hyssopus plants (two years old), cut about $20 \mathrm{~cm}$ from the top. There are data (Ahn \& Chung, 2000; Economou et al., 2007) about different degrees of allelopathic activity of infusions, obtained at different temperatures. In this study we prepared two types of infusions: 1) Hot infusion (HI) - the dried stems, leaves and flowers were covered with boiling distilled water, left for $60 \mathrm{~min}$ and then allowed to cool to room temperature; 2) Cold infusion (CI) - the dried hyssopus tissues were placed in distilled water and left to stay for $24 \mathrm{~h}$ at room temperature. The infusions were then filtered through filter paper, directly utilized for germination test and then were stored at less $5{ }^{\circ} \mathrm{C}$ until bioassayed in root elongation test. Economou et al. (2007) tested allelopathic influence of other aromatic plant (oregano) at concentrations in the $18.75-150 \mathrm{~g} / \mathrm{L}$ range. We prepared infusions at three concentrations: two in the same range, tested by Economou et al. (2007) - 17.5 and $52.5 \mathrm{~g} / \mathrm{L}$, and one at concentration, normally used as a therapeutic tea by the humans $(3.5 \mathrm{~g} / \mathrm{L})$ (Nikolova \& Manolov, 2002), because a dosage threshold exists for each medicinal plant as it does for synthetic pharmaceuticals (Nunes \& Carvalho, 2003).

\section{Germination and root elongation of seeds, germinated in hyssopus infusions}

Twenty seeds of $C$. sativus and $T$. aestivum, respectively, were placed on filter paper in each of fourteen Petri dishes (11 cm in diameter). Five $\mathrm{mL}$ of each infusion or distilled water, as a control, was applied to the seeds. The dishes were sealed and incubated at $25 \pm 1{ }^{\circ} \mathrm{C}$ for 72 $\mathrm{h}$. The percent of germinated seeds was recorded, and the length of the roots of germinated seeds was measured. Seeds that did not germinate were not included in the root elongation test. Three replications of each treatment were done.

\section{Root elongation of seeds germinated in water before being treated with infusions}

Twenty five seeds of $C$. sativus and T. aestivum, respectively, were placed on filter paper in each of fourteen Petri dishes (11 cm in diameter), containing $5 \mathrm{~mL}$ of distilled water. The dishes were sealed and incubated at $25 \pm 1{ }^{\circ} \mathrm{C}$ for $48 \mathrm{~h}$. Twenty germinated seeds with equal length of roots $(\sim 1 \mathrm{~cm})$ were selected and placed on filter paper in each of another fourteen Petri dishes. Five $\mathrm{mL}$ of each water infusion or distilled water as a control were added to each of fourteen Petri dishes. The dishes were sealed and incubated at $25 \pm 1{ }^{\circ} \mathrm{C}$ for $24 \mathrm{~h}$. The root length was measured and the data expressed as a percentage of control values. Three replications of each treatment were done.

\section{Allium cepa test}

Thirty seeds of $A$. cepa were placed on filter paper in each of three Petri dishes (11 cm in diameter), containing $5 \mathrm{~mL}$ of distilled water. The Petri dishes were sealed and incubated at $25 \pm 1{ }^{\circ} \mathrm{C}$ for $72 \mathrm{~h}$. Twenty germinated seeds with equal length of roots $(\sim 1 \mathrm{~cm})$ were removed and placed on filter paper in each of another three Petri dishes. Five $\mathrm{mL}$ of hot water infusion $(3.5 \mathrm{~g} / \mathrm{L})$ were added to one dish, and incubated at $25 \pm 1{ }^{\circ} \mathrm{C}$ for $24 \mathrm{~h}$. Distilled water was used as a negative control and methyl methanesulfonate $(11 \mathrm{mg} / \mathrm{L})$ was used as a positive control. After treatment, the roots were fixed in Clarke's fixative (95\% ethanol: acetic acid glacial, 3:1) for $90 \mathrm{~min}$, hydrolysed in $3 \mathrm{~N} \mathrm{HCl}$ for $8 \mathrm{~min}$ and in $45 \%$ acetic acid $\left(\mathrm{CH}_{3} \mathrm{COOH}\right)$ for $30 \mathrm{~min}$ at room temperature and stained for $90 \mathrm{~min}$ in $4 \%$ acetocarmine. After staining, the terminal root tips (1-2 mm) were cut off and squashed in $45 \% \mathrm{CH}_{3} \mathrm{COOH}$. The microscopic analysis included the mitotic index and scoring of aberrant cells. Each sample consisted of six root meristems. At least 1000 cells of each root meristem were analysed. The mitotic index was determined as a ratio between the number of cells in mitosis and the total number of analysed cells. The 
index of each phase of mitotic division was calculated as a ratio between the cell number in the respective period and the number of dividing cells.

\section{Statistical analyses}

We processed the experimental data by Student's t-test. In growth and root inhibition tests we choose as an experimental unit the root. The calculations were carried out on the assumption that roots used in each treatment made one sample, and each sample was tested against the control sample. In Allium cepa test we choose as an experimental unit the cell, instead of the root. The calculations were carried out on the assumption that all the cells of the six root meristems made one sample, and each sample was tested against the negative control.

\section{RESULTS}

Hyssopus infusions at concentration of $3.5 \mathrm{~g} / \mathrm{L}$ exerted effects, similar to those observed at concentration of $17.5 \mathrm{~g} / \mathrm{L}$ (data not shown). So we presented the effects of two higher concentrations $-17.5 \mathrm{~g} / \mathrm{L}$ and $52.5 \mathrm{~g} / \mathrm{L}$.

\section{Germination of seeds}

Table 1 shows the results of the influence of hot (HI) and cold (CI) hyssopus water infusions on the germination of $C$. sativus and T. aestivum seeds. Seeds of both species germinated to about $90 \%$ in water after $3 \mathrm{~d}$. Seed germination of $C$. sativus was not influenced significantly by any treatment (range 86.67 to $81.67 \%$ germination). Treatment with the lower concentration of $\mathrm{HI}$ and $\mathrm{CI}$ inhibited germination of T. aestivum at the same rate $(81.67 \%$ germination). This inhibitory effect significantly increased at higher concentration of $\mathrm{HI}$ (71.67\% germination). When T. aestivum seeds germinated in $\mathrm{CI}$ at concentration of $52.5 \mathrm{~g} / \mathrm{L}$ the inhibitory effect was stronger (63.33\% germination).

Table 1. Effect of hot and cold water infusions from aerial parts of micropropagated hyssopus on germination of C.sativus L. and T. aestivum L.

\begin{tabular}{lcc}
\hline \multirow{1}{*}{ Sample } & \multicolumn{2}{c}{ Concentrations } \\
& $\begin{array}{c}17.5 \mathrm{~g} / \mathrm{L} \\
\text { Germination, } \%\end{array}$ & $\begin{array}{c}52.5 \mathrm{~g} / \mathrm{L} \\
\text { Cucumis }\end{array}$ \\
\hline Cormination, $\%$ \\
\hline Hot infusion $\mathrm{L}$. \\
Cold infusion & $91.65 \pm 3.60$ & $91.65 \pm 3.60$ \\
& $86.67 \pm 4.43$ & $85.00 \pm 4.65$ \\
Control & $86.67 \pm 4.43$ & $81.67 \pm 5.04$ \\
Hot infusion & Triticum & aestivum $\mathrm{L}$. \\
Cold infusion & $93.33 \pm 3.25$ & $93.33 \pm 3.25$ \\
\hline
\end{tabular}

Data are expressed as means $\pm \mathrm{SE}$ (standard error), ${ }^{* *} p \leq 0.01$, ${ }^{* * *} p \leq 0.001$; Sample: C. sativus L. $(\mathrm{n}=20)$ and T. aestivum L. $(n=20)$ seeds, germinated in water infusions, made from micropropagated Hyssopus officinalis L. over a period of $72 \mathrm{~h}$; Control - distilled water.

\section{Root elongation of seeds germinated in infusions}

Root length of both species, germinated in hyssopus infusions, was reduced significantly in comparison with the control (Table 2). Root elongation of C. sativus was inhibited by 26.73 and $22.80 \%$ upon the treatment with the lower concentration of $\mathrm{HI}$ and CI, respectively. The growth inhibitory effect increased at the higher concentration: $44.49 \%(\mathrm{HI})$ and $58.10 \%$ (CI). The inhibitory effect was stronger in T. aestivum: inhibition of $33.17 \%(\mathrm{HI})$ and $56.18 \%(\mathrm{CI})$ upon the treatment with the lower concentration. Treatment with the higher concentration of both infusions inhibited root growth by about $74.00 \%$ compared with the control.

\section{Root elongation of seeds germinated in water before being treated with infusions}

Treatment with the lower concentration of $\mathrm{HI}$ and CI inhibited root elongation of $C$. sativus by 23.71 and $22.71 \%$, respectively, compared with the control (Table 2 ). The effect of the higher concentration of HI was similar (inhibition of $27.36 \%$ ). We observed stronger inhibition of C. sativus root growth at the higher concentration of CI $(43.90 \%)$ in comparison with other treatments. Treatment with the lower concentration of HI inhibited the root elongation of T. aestivum by $32.39 \%$ compared with the control. The higher concentration of HI caused stronger effect: inhibition of $42.16 \%$. CI had similar effect: inhibition of 28.30 and $42.25 \%$ at the lower and the higher concentration, respectively.

\section{Allium cepa test}

Table 3 shows the results of the influence of hot hyssopus infusion $(3.5 \mathrm{~g} / \mathrm{L}$, for $24 \mathrm{~h})$ on the mitotic index and on the frequency of mitotic phases. Upon the treatment the mitotic index was significantly decreased in comparison with those exposed to water only. The treatment changed the mitotic phase distribution, as expressed mainly by lower prophase ratios than the control.

Treatment with hyssopus significantly increased the percent of chromosome aberrations in mitotic cells (about threefold compared with the control) (Table 4). Hyssopus induced a variety of different chromosome aberrations. Anaphases and telophases with bridges and fragments were the most frequent kinds of aberrations and anaphases with vagrant chromosomes were the second. Metaphases with spindle abnormalities were also scored but at a lesser frequency. The percent of abnormal

\begin{tabular}{r|r}
\hline Rev. Bras. Farmacogn. & \multirow{2}{*}{515} \\
Braz. J. Pharmacogn. & \\
20(4): Ago./Set. 2010 &
\end{tabular}


interphase cells also increased significantly upon the treatment with hyssopus. The infusion induced a higher percentage of binucleated cells compared with the control.
A similar trend was observed in the frequency of cells with micronuclei, but the difference with the control was not significant.

Table 2. Effect of hot and cold water infusions from aerial parts of micropropagated hyssopus on root elongation of $C$. sativus L. and T. aestivum L.: 1) seeds germinated in the infusions for $72 \mathrm{~h}$ and 2) seeds germinated in water for $48 \mathrm{~h}$ and treated for $24 \mathrm{~h}$

\begin{tabular}{|c|c|c|c|c|}
\hline \multirow[b]{2}{*}{ Sample } & \multicolumn{2}{|c|}{ Seeds germinated in the infusions for $72 \mathrm{~h}$} & \multicolumn{2}{|c|}{ Seeds germinated in water for $48 \mathrm{~h}$ and treated for $24 \mathrm{~h}$} \\
\hline & $\begin{array}{l}\text { Root length, } \mathrm{mm} \\
(\% \text { compared to the } \\
\text { control) } 17.5 \mathrm{~g} / \mathrm{L}\end{array}$ & $\begin{array}{c}\text { Root length, mm }(\% \\
\text { compared to the control) } \\
52.5 \mathrm{~g} / \mathrm{L}\end{array}$ & $\begin{array}{l}\text { Root length, mm } \\
\text { (\% compared to the } \\
\text { control) } 17.5 \mathrm{~g} / \mathrm{L}\end{array}$ & $\begin{array}{c}\text { Root length, mm (\% } \\
\text { compared to the control) } 52.5 \\
\mathrm{~g} / \mathrm{L}\end{array}$ \\
\hline $\begin{array}{l}\text { Control (root } \\
\text { length, } \mathrm{mm} \text { ) }\end{array}$ & \multicolumn{4}{|c|}{$\begin{array}{c}\text { Cucumis sativus } \mathrm{L} \text {. } \\
46.01 \pm 2.62\end{array}$} \\
\hline Hot infusion & $33.71 \pm 3.24 * *(73.27)$ & $25.54 \pm 2.12 * * *(55.51)$ & $35.10 \pm 2.59 * *(76.29)$ & $33.42 \pm 1.94 * * *(72.64)$ \\
\hline Cold infusion & $35.52 \pm 2.43 * *(77.20)$ & $19.28 \pm 1.14 * * *(41.90)$ & $35.56 \pm 2.89 * *(77.29)$ & $25.81 \pm 1.05^{* * *}(56.10)$ \\
\hline Control & \multicolumn{4}{|c|}{$\begin{array}{l}\text { Triticum aestivum L. } \\
54.56 \pm 3.63\end{array}$} \\
\hline Hot infusion & $36.46 \pm 2.70 * * *(66.83)$ & $13.89 \pm 1.59 * * *(25.46)$ & $36.89 \pm 2.90 * * *(67.61)$ & $31.56 \pm 1.93 * * *(57.84)$ \\
\hline Cold infusion & $23.91 \pm 1.40 * * *(43.82)$ & $14.66 \pm 1.66 * * *(26.87)$ & $39.12 \pm 2.32 * * *(71.70)$ & $31.51 \pm 2.60 * * *(57.75)$ \\
\hline
\end{tabular}

Data are expressed as means \pm SE (standard error), ${ }^{*} p \leq 0.01,{ }^{* * *} p \leq 0.001$; Sample: $C$. sativus L. $(\mathrm{n}=20)$ and T. aestivum L. (n=20) seeds; Control - distilled water.

Table 3. Effect of treatment of hot water infusion $(3.5 \mathrm{~g} / \mathrm{L})$ of micropropagated hyssopus for $24 \mathrm{~h}$ on mitotic index and phase indices in root tip meristems of Allium cepa $\mathrm{L}$.

\begin{tabular}{lccccccc}
\hline Sample & $\begin{array}{c}\text { Number of } \\
\text { cells analysed }\end{array}$ & $\begin{array}{c}\text { Number of } \\
\text { dividing cells }\end{array}$ & MI\% $( \pm$ SD) & $\begin{array}{c}\text { Prophase PhI\% } \\
( \pm \text { SD })\end{array}$ & $\begin{array}{c}\text { Metaphase } \\
\text { PhI\% }( \pm \text { SD })\end{array}$ & $\begin{array}{c}\text { Anaphase } \\
\text { PhI\% }( \pm \text { SD })\end{array}$ & $\begin{array}{c}\text { Telophase } \\
\text { PhI\% } \%( \pm S D)\end{array}$ \\
\hline NC & 6884 & 390 & $5.67( \pm 0.23)$ & $32.82( \pm 0.47)$ & $25.90( \pm 0.44)$ & $16.92( \pm 0.38)$ & $24.36( \pm 0.43)$ \\
PC & 6991 & 258 & $3.69 * * *( \pm 0.19)$ & $20.54 * * *( \pm 0.40)$ & $31.78 * *( \pm 0.47)$ & $26.74 * *( \pm 0.44)$ & $20.93( \pm 0.41)$ \\
HI & 6942 & 330 & $4.75 *( \pm 0.21)$ & $23.64 * *( \pm 0.43)$ & $28.79( \pm 0.45)$ & $21.52( \pm 0.41)$ & $26.06( \pm 0.44)$ \\
\hline
\end{tabular}

Data are expressed as means $\pm \mathrm{SD}$ (standard deviation, expressed per cell) in six root meristems, analysed per treatment, $* p \leq 0.05, * * p$ $\leq 0.01, * * * p \leq 0.001$; Sample: NC: negative control (distilled water); PC: positive control (methyl methanesulfonate, $11 \mathrm{mg} / \mathrm{L}$ ); HI: hot water infusion made from the aerial parts of micropropagated Hyssopus officinalis $\mathrm{L}$.

Table 4. Effect of treatment of hot water infusion $(3.5 \mathrm{~g} / \mathrm{L})$ of micropropagated hyssopus for $24 \mathrm{~h}$ on mitotic and interphase abnormalities in root tip meristems of Allium cepa L.

\begin{tabular}{|c|c|c|c|c|c|c|c|c|c|}
\hline \multirow[b]{2}{*}{ Sample } & \multicolumn{5}{|c|}{ Abnormalities, $\%$ of mitotic cells } & \multicolumn{4}{|c|}{ Abnormalities, $\%$ of interphase cells } \\
\hline & 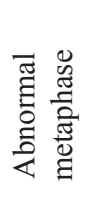 & 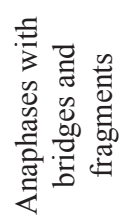 & 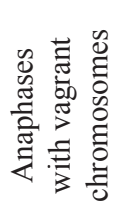 & 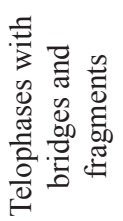 & 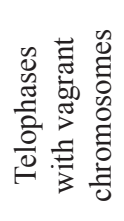 & $\begin{array}{l}\text { Total } \\
\text { abnormalities in } \\
\text { mitotic cells, \% } \\
( \pm \text { SD })\end{array}$ & $\begin{array}{l}\text { Cells with } \\
\text { micronuclei, \% } \\
\quad( \pm \mathrm{SD})\end{array}$ & $\begin{array}{c}\text { Binucleated } \\
\text { cells, \% }( \pm \mathrm{SD})\end{array}$ & $\begin{array}{c}\text { Total } \\
\text { abnormalities in } \\
\text { interphase cells, } \\
\%( \pm \mathrm{SD})\end{array}$ \\
\hline $\mathrm{NC}$ & 0.26 & 0.51 & 0.26 & 0.26 & 0.26 & $1.54( \pm 0.12)$ & $0.28( \pm 0.05)$ & $0.03( \pm 0.02)$ & $0.31( \pm 0.06)$ \\
\hline $\mathrm{PC}$ & 0.39 & 6.20 & 3.10 & 5.04 & 2.33 & $17.05^{* * *}( \pm 0.38)$ & $0.48( \pm 0.07)$ & $0.23 * * *( \pm 0.05)$ & $0.71 * * *( \pm 0.08)$ \\
\hline HI & 0.61 & 1.52 & 0.91 & 1.21 & - & $4.24 * *( \pm 0.20)$ & $0.48( \pm 0.07)$ & $0.15 * *( \pm 0.04)$ & $0.64 * *( \pm 0.08)$ \\
\hline
\end{tabular}

Data are expressed as means \pm SD (standard deviation, expressed per cell) in six root meristems, analysed per treatment, $* p \leq 0.05$, ${ }^{* *} p \leq 0.01, * * * p \leq 0.001$; Sample: NC: negative control (distilled water); PC: positive control (methyl methanesulfonate, $11 \mathrm{mg} / \mathrm{L}$ ); HI: hot water infusion made from the aerial parts of micropropagated Hyssopus officinalis L. 


\section{DISCUSSION}

The determined effects of hyssopus demonstrated the existence of water soluble compounds that possess allelopathic activity. The inhibitory effect of infusions was more pronounced at concentrations of 17.5 and $52.5 \mathrm{~g} / \mathrm{L}$. It might be speculated that the concentration of $17.5 \mathrm{~g} / \mathrm{L}$ was the dosage threshold in the case of three concentrations tested $(3.5,17.5$ and $52.5 \mathrm{~g} / \mathrm{L})$ in our study.

According to Kruse et al. (2000) allelochemicals might cause inhibition of seed germination and/or seedling growth. While seed germination was affected significantly only at higher concentration of hot and cold infusions in T. aestivum, all infusions reduced root elongation in both test species. These results confirm the statement of Chung \& Miller (1995) that root growth is more sensitive than germination. According to Nilsen et al. (1999) such an effect might be due to the rapid germination of the seeds tested. The growth inhibitory effect was stronger when tested seeds germinated in the infusions in comparison with the effect on germinated in water seeds. It might be speculated that hyssopus water soluble compounds caused stronger inhibition of root elongation at early stage of growth.

The results obtained from testing the germination and root elongation revealed that inhibitory effect of hyssopus was stronger in T. aestivum than in C. sativus and confirmed the observations of Einhellig (1995) that plants may be selective in their responses to allelochemicals.

There were not significant differences between the effects of infusions obtained at different water temperatures on root elongation of $T$. aestivum. The root elongation of $C$. sativus was most inhibited by cold infusion at concentration of $52.5 \mathrm{~g} / \mathrm{L}$. The same infusion caused also strongest inhibition on germination of both tested species. This effect might be due to the presence of specific compounds, which are inactivated by the temperature treatment.

There are possibilities of application of hyssopus in ecological agriculture (Jankovský \& Landa, 2002), but for most farmers sole medicinal plants cultivation is not possible. Production of phytotoxic symptoms by certain plants and their residues is a well established phenomenon (Duke, 1990). In our study root growth of two traditional food crops was reduced significantly upon the treatment with hyssopus infusions. These results supported the statement of Nazir et al. (2007) that medicinal plants with allelopathic potential might be grown satisfactorily under traditional agriculture systems if whole plants are harvested from the agricultural fields.

In Allium cepa test we choose to test the genotoxic potential of infusion that exerted the lowest growth inhibition effect (hot infusion, $3.5 \mathrm{~g} / \mathrm{L}$ for $24 \mathrm{~h}$ ). The observed inhibition of mitotic activity demonstrated that hyssopus exerted a cytotoxic effect. Another sign of cytotoxic influence was the interference in the cell cycle kinetics (Amin, 2002). Hyssopus induced chromosome aberrations in Allium cepa root tips. Compared with the positive control, hyssopus had less genotoxic effect. However, the different types of aberrations produced by the test infusion suggest its genotoxic potential. The most frequent kinds of aberrations in our study were anaphases and telophases with bridges and fragments. When double strand break of DNA happen, broken chromosome ends without telomeres become "sticky" and may fuse with other broken chromosome ends. The results of such chromosomal rearrangements are fragments and bridges observed in mitotic cells of the first cell cycle after treatment (Maluszynska \& Juchimiuk, 2005). The occurrence of abnormal metaphases and vagrant chromosomes indicated that hyssopus caused inhibition of spindle formation (Rank, 2003). The detection of a binucleate condition in Allium indicated that hyssopus inhibited cytokinesis.

\section{CONCLUSION}

The results suggest that hyssopus water infusions contain secondary metabolites that exhibit allelopathic effects at early stages of growth of other plants under laboratory conditions. The growth inhibitory effect was stronger in T. aestivum (belonging to monocotyledonous species) than in C. sativus (belonging to dicotyledonous species). Hyssopus also exerted mitodepressive effect on the rate of cell division and genotoxic effect in Allium cepa root tip cells.

\section{ACKNOWLEDGMENTS}

We would like to thank Yordanka Slavova from the Agricultural Institute-Shumen and Polina Kirilova and Krasimir Tachev for support and assistance.

\section{REFERENCES}

Ahn JK, Chung IM 2000. Allelopathic potential of rice halls on germination and seedling growth of barnyardgrass. Agron J 92: 1162-1167.

Amin AW 2002. Cytotoxicity testing of sewage water treatment using Allium cepa chromosome aberrations assay. Pakistan J Biol Sci 5: 184-188.

Angelini G, Carpanese G, Cioni PL, Morelli I, Macchia M, Flamini G 2003. Essential oils from mediterranean lamiaceae as weed germination inhibitors. J Agric Food Chem 51: 6158-6164.

Arminante F, De Falco E, De Feo V, De Martino L, Mancini E, Quaranta E 2006. Allelopathic activity of essential oils from mediterranean Labiatae. Acta Hort (ISHS) 723: 347-356.

Basotra R, Chauhan S, Todaria NP 2005. Allelopathic effects of medicinal plants on food crops in Garhwal Himalaya. J Sust Agric 26: 43-56.

Chou C-H 1999. Roles of allelopathy in plant biodiversity and sustainable agriculture. Cr Rev Plant Sci 18: 609-636.

Chun S-S, Vattem DA, Lin Y-T, Shetty K 2005. Phenolic 
antioxidants from clonal oregano (Origanum vulgare) with antimicrobial activity against Helicobacter pylori. Food Chem 91: 341-345.

Chung IM, Miller DA 1995. Allelopathic influence of nine forage grass extracts on germination and seedling growth of alfalfa. Agron J 87: 767-772.

Đikić M 2005. Allelopathic effect of aromatic and medicinal plants on the seed germination of Galinsoga Parviflora, Echinochloa Crus-Galli and Galium Molugo. Herbologia 6: 54-60.

Dudai N, Poljakoff-Mayber A, Mayer AM, Putievsky E, Lerner HR 1999. Essential oils as allelochemicals and their potential use as bioherbicides. J Chem Ecol 25: 10791089.

Duke SO 1990. Natural pesticides from plants. In: Janick J and Simon JE (eds.): Advances in new crops. Timber Press, Portland, OR. p. 511-517.

Economou G, Travlos IS, Folinas A, Karamanos AJ 2007. Greek oregano (Origanum vulgare ssp. hirtum) as allelopathic plant. J Food Agriculture \& Environment 5: 348-351.

Einhellig FA 1995. Mechanism of action of allelochemicals in allelopathy. In: Inderjit et al. (eds.): Allelopathy: Organisms, processes, and applications. Am Chem Soc Symp Ser 582: 96-116.

Ganchev G 1995. Hyssopus officinalis L. In: I.Bondev (ed.): Chorological atlas of the medicinal plants in Bulgaria. Acad. Press, Sofia. p. 111-112.

Jankovský M, Landa T 2002. Genus Hyssopus L.-recent knowledge. Hort Sci 29: 119-123.

Kazinczi G 1999. Research on allelopathy in Hungary. In: S.S. Narwal (ed.). Allelopathy Update: Volume 1, International Status, Enfield, NH: Science Publishers, Inc. p. 49-64.

Kruse M, Strandberg M, Strandberg B 2000. Ecological Effects of Allelopathic Plants-A Review. National Environmental Research Institute-Technical Report No. 315. Silkeborg, Denmark. p. 64.

Maluszynska J, Juchimiuk J 2005. Plant genotoxicity: a molecular cytogenetic approach in plant bioassays. Arh Hig Rada Toksikol 56: 177-184.

Nanova Zh, Slavova Y, Nenkova D, Ivanova I 2007. Microclonal vegetative propagation of hyssop (Hyssopus officinalis L.). Bulg J Agric Sci 13: 213-219.

Nazir T, Uniyal AK, Todaria N 2007. Allelopathic behaviour of three medicinal plant species on traditional agriculture crops of Garhwal Himalaya, India. Agroforest Syst 69: 183-187.

Nikolova M, Manolov P 2002. Herbs book of reference. "P. Beron", Sofia.

Nilsen ET, Walker JF, Miller OK, Semones SW, Lei TT, Clinton BD 1999. Inhibition of seedling survival under Rhododendron maximum (Ericaceae): Could allelopathy be a cause? - Am J Bot 86 (11): 1597-1605.

Nunes WB, Carvalho S de 2003. Evaluation of the mutagenic potential of Cochlospermum regium in Drosophila melanogaster male germ cells. Genet Mol Biol 26: 545549.

Rank J 2003. The method of Allium anaphase-telophase chromosome aberration assay. Ekologija Vilnius 1: 38 42.

Shetty K 2001. Biosynthesis and medical applications of rosmarinic acid. J Herbs, Spices \& Medic Plants 8: 161181. 